\title{
The Use of Remote Sensing in Light Use Efficiency Based Models of Gross Primary Production: A Review of Current Status and Future
}

\section{Requirements}

Thomas Hilker ${ }^{1^{*}}$, Nicholas C. Coops ${ }^{1}$, Michael A. Wulder ${ }^{2}$, T. Andrew Black ${ }^{3}$, Robert D. Guy ${ }^{4}$

1- Faculty of Forest Resources Management, University of British Columbia, 2424 Main Mall, Vancouver, BC, V6T 1Z4, Canada

2-Canadian Forest Service (Pacific Forestry Centre), Natural Resources Canada, 506 West Burnside Road, Victoria, BC, V8Z 1M5, Canada

3-Faculty of Land and Food Systems, University of British Columbia, 2357 Main Mall, Vancouver, BC, V6T 1Z4, Canada

Robert D. Guy

4-Department of Forest Sciences

University of British Columbia, 2424 Main Mall, Vancouver, BC, V6T 1Z4, Canada

* corresponding author:

Thomas Hilker

Phone: +1 (604) 827 4429, Fax :+1 (604) 822 9106, thomas.hilker@ubc.ca

\section{Pre-print of published version.}

\section{Reference:}

Hilker, T., Coops, N.C., Wulder, M.A., Black, T.A., Guy, R.D. 2008. The use of remote sensing in light use efficiency based models of gross primary production: a review of current status and future requirements. Science of the Total Environment. 404: 411-423

DOI:

doi:10.1016/j.scitoteenv.2007.11.007

\section{Disclaimer:}

The PDF document is a copy of the final version of this manuscript that was subsequently accepted by the journal for publication. The paper has been through peer review, but it has not been subject to any additional copy-editing or journal specific formatting (so will look different from the final version of record, which may be accessed following the DOI above depending on your access situation). 


\section{Abstract}

Global estimation and monitoring of plant photosynthesis (known as Gross Primary Production - GPP) is a critical component of climate change research. Modeling of carbon cycling requires parameterization of the land surface, which, in a spatially continuous mode, is only possible using remote sensing. The increasing availability of high spectral resolution satellite observations with global coverage and high temporal frequency has allowed the scientific community to revisit a number of existing approaches for modeling GPP, and reassess the potential for using remotely sensed inputs. In this paper we examine the current status and future requirements of modeling global GPP thereby focussing on the light use efficiency approach which expresses GPP as product of the photosynthetically active radiation (PAR), the fraction of PAR being absorbed by the plant canopy $\left(f_{\mathrm{PAR}}\right)$ and the efficiency $\underline{\varepsilon}$ with which this absorbed PAR can be converted into biomass. The capacity of remote sensing to provide the critical input variables for this approach is investigated and key issues are identified and discussed for future research.

Keywords: remote sensing, GPP, photosynthesis, light use efficiency, fPAR, carbon fluxes 


\section{Introduction}

Terrestrial ecosystems absorb approximately 60 Gt of carbon annually through the physiological process of photosynthesis (Janzen, 2004), also referred to as Gross Primary Production (GPP) (Hamilton et al., 2002). Simultaneously, autotrophic and heterotrophic organisms release about the same amount of carbon back into the atmosphere thereby closing the terrestrial carbon cycle. As the estimated annual turnover between the atmosphere and terrestrial ecosystems is approximately $120 \mathrm{Gt}$, considerably greater than the amount of fossil fuel emissions (5 Gt), small alterations in the terrestrial carbon balance are likely to have a significant impact on atmospheric $\mathrm{CO}_{2}$ concentrations. As a result, there is a need for a better understanding of the dynamics of carbon fluxes between biosphere and atmosphere to help quantifying potential changes due to increased atmospheric $\mathrm{CO}_{2}$ rates (Comins and McMurtrie 1993; Luo and Reynolds 1999). Global monitoring and prediction of GPP over forested and agricultural environments is therefore an ultimate goal of Earth climate change research seeking universal, generic modelling approaches applicable across multiple biomes and a wide variety of vegetation types.

Modeling of carbon cycling requires parameterization of the land surface (Hall et al., 1995), which, in a spatially continuous mode and on a regularly basis, is only possible using remote sensing. Modeling GPP from remote sensing is largely based on the awareness that plant physiological properties are related to the biochemical composition of plant foliage, and that this composition is reflected in the spectral radiation properties of leaves. Since the launch of the first satellite based sensors in the 1970s the remote 
sensing community has been limited in the number and width of the spectral wavebands available, and observation frequencies of existing sensors were incapable of detecting the spatial and temporal variability of primary production of vegetation. Recently, the advent of high spectral resolution optical sensors, capable of detecting changes in leaf spectral properties with a high temporal frequency (Prince and Goward, 1995) has allowed the scientific community to revisit a number of existing approaches for modeling GPP, and reassess the potential for using remotely sensed inputs, with the ultimate aim of driving GPP models entirely from satellite based observations (Running et al., 2004; Rahman et al., 2005). This paper reviews the current status of determining GPP from remotely sensed inputs and addresses future requirements for developing remote sensing based models of the terrestrial carbon cycle, specifically on approaches based on the light use efficiency concept.

\section{Light use efficiency based modeling of primary production}

One of the most widely applied concepts for modeling GPP is the light use efficiency approach of Monteith (1972; 1977) (e.g. Prince, 1991; Goetz and Prince, 1999; Heinsch et al., 2002; Turner et al., 2003a,b), which expresses GPP as the product of the absorbed photosynthetically active radiation (PAR) $\left(\mu \mathrm{mol} \mathrm{m} \mathrm{m}^{-2} \mathrm{~s}^{-1}\right)$, defined as absorbed solar radiation between $400-700 \mathrm{~nm}$ wavelength, and the efficiency, with which the absorbed PAR can be converted into biomass:

$$
G P P=P A R \times f_{P A R} \times \varepsilon
$$


where $\underline{f}_{\text {PAR }}$ represents the fraction of PAR absorbed by the canopy and $\underline{\varepsilon}\left(\mathrm{g} \mathrm{MJ}^{-1}\right)$ is the photosynthetic efficiency term. The light use efficiency concept is based on the functional convergence theory (Field, 1991) hypothesizing that plants are scaling canopy leaf area and light harvesting by the availability of resources as a result of evolutionary processes in order to optimize their carbon fixation (Goetz et al., 1999). Detailed development and discussion of the underlying concepts behind the light use efficiency model are described in extensive studies and reviews by Field (1991), Reich et al. (1997) and Goetz and Prince (1999).

The amount of photosynthetically active radiation absorbed by a plant canopy $\rho_{a}$ is defined as the difference between the PAR incident upon the canopy $(\underline{Q})$, the amount of PAR being reflected from the canopy $\left(\underline{\mathrm{r}}_{\mathrm{r}}\right)$, and PAR being transmitted through the canopy $\left(\underline{\tau}_{t}\right)($ Beer-Lambert law):

$$
\rho_{a}=Q-\rho_{r}-\tau_{t}
$$

For a given time, $\varrho_{\underline{r}}$ and $\underline{\tau}_{\underline{t}}$ are a function of the leaf surface area (Sellers, 1985) parameterized by the leaf area index (LAl) defined as half the total foliage area per unit ground surface area (Chen and Black, 1992). Because of temporal variations in solar irradiance, chlorophyll content (Dawson et al., 2003) and leaf-sun geometry (Chen and Black, 1992) the amount of solar radiation being absorbed by a plant canopy varies diurnally as well as seasonally (Chen, 1996). 
$\underline{\varepsilon}$ is determined by the most limiting of a large number of environmental stresses restraining the photochemical reaction process, such as nutrition supply, water and temperature, depends on individual vegetation types, and, as a result, varies greatly within space and time (Field and Mooney 1986; Prince and Goward 1996; Turner et al. 2003b). The biochemical process driving $\underline{\varepsilon}$ is known as photoprotection (Figure 1). In situations where plants receive more sunlight than they can actually use, light harvesting is being regulated to balance absorption and utilization of quanta as excessive light energy can cause photo-oxidative damage to the leaf (Demmig-Adams, 1990). The mechanism regulating the use of absorbed light is uniformly controlled by a group of leaf pigments named xanthophylls which occur over a broad range of species (Bilger et al., 1989; Bilger and Björkman 1990; Demmig-Adams and Adams, 2000; Demmig-Adams et al., 1998). Under excessive light conditions, the xanthophyll cycle pigment violaxanthin is de-epoxidized rapidly via intermediate antheraxanthin to zeaxanthin and this reaction is reversed when light is limiting. Antheraxanthin, as well as zeaxanthin, have photo-protective structures accepting excessive light energy from the antenna pigments of Photosystem II and safely dissipating it as heat (DemmigAdams and Adams, 1996). Recently, a second xanthophyll cycle, the lutein cycle, has been discovered (Bungard, 1999), which is believed, within some species, to work in parallel. Photo-protection is also closely related to active emittance of light quanta in leaves, known as chlorophyll fluorescence (Demmig-Adams and Adams, 1996). 
A

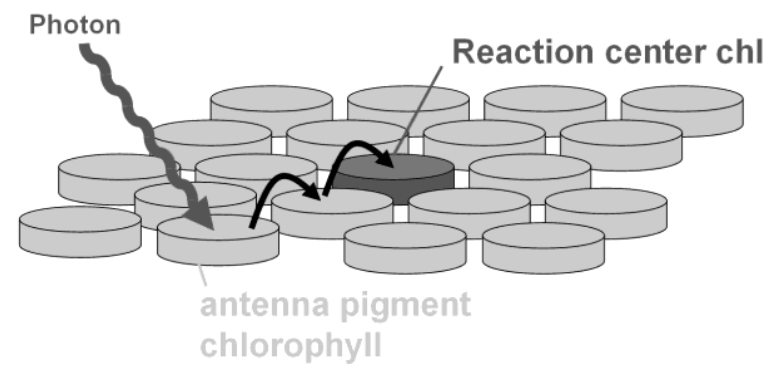

C

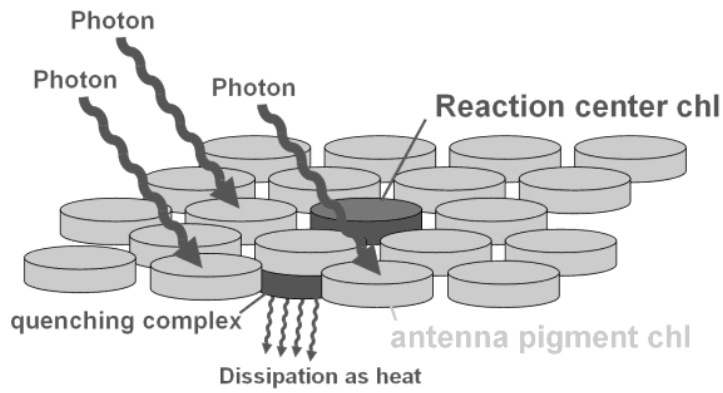

B

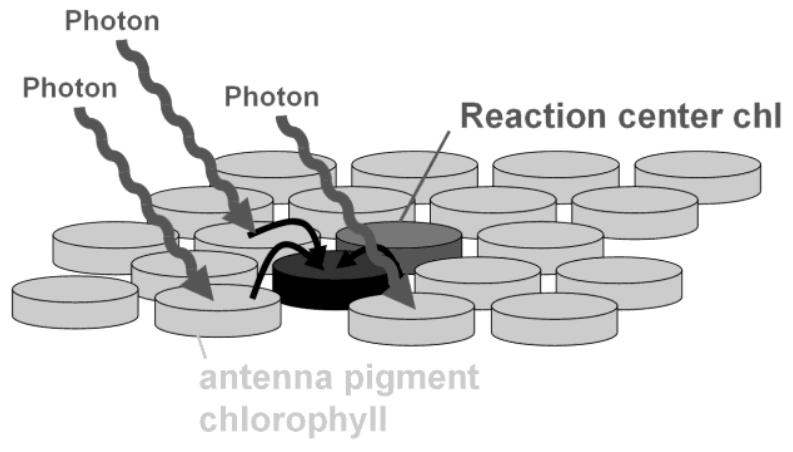

Figure 1: Schematic drawing of the photoprotective mechanism inside the light harvesting complex (LHC) of a leaf. A: Light is harvested by antenna pigments and the energy is transferred to the reaction center. B: In case plants receive more light energy than they can actually use, this excessive energy accumulates inside the LHC (illustrated by the black disk). Excessive radiation energy can potentially cause photo-oxidative damage to the photosynthetic apparatus of the leaf. C: The excessive radiation energy is safely dissipated as heat by means of a quenching complex. At the same time chlorophyll fluorescence is increased thereby reemitting photons into space.

\section{Current status of determining GPP from remote sensing}

\subsection{Photosynthetically active radiation}

While the extraterrestrial radiation budget and its wavelength distribution are well known and relatively constant, the terrestrial reception of PAR is altered by a dynamically changing atmosphere (Van Laake and Sanchez-Azofeifa, 2004). Atmospheric radiative transfer is driven by absorption, molecular (Raleigh) and particle (Mie) scattering effects attenuating the amount of solar radiation received by the earth surface (Szeicz, 1974; 
Rao, 1984; Baker and Frouin, 1987). Early estimates of broad scaled PAR were obtained from networks of surface pyranometers (Bland and Clayton, 1994; Bland, 1996), allowing long-term time series from well maintained and calibrated instruments. This method, however, is insufficient for global modeling since estimates of PAR are restricted to a few discrete observations (Frouin and Pinker, 1995). Since the launch of the first multispectral satellite sensors, numerous approaches have been developed to infer large scaled PAR from top of the atmosphere solar radiance using optical modeling (Sellers et al., 1995) to allow spatially exhaustive estimates of broadband and shortwave irradiance (Eck and Dye, 1991; Frouin and Gautier, 1992; Pinker and Laszlo, 1992). PAR is thereby often defined as a fraction of the reflected shortwave radiation (e.g., Tarpley, 1979; Gautier et al., 1980; Pinker and Ewing, 1985; Running et al., 1999), which is sufficient for most biological applications (Blackburn and Proctor, 1983; Weiss and Norman, 1985).

Recently, research focuses on incorporating the temporal and spatial variability of solar irradiance with respect to changing atmospheric conditions into global estimates of PAR to obtain highly accurate inputs for climate change modeling. Atmospheric conditions are currently assessed on a global scale by the Moderate Resolution Imaging Spectroradiometer (MODIS), on board of NASA's EOS (earth observation system) satellites Terra and Aqua. The MODIS Atmospheric Profile products (MOD04-MOD07) consist of total-ozone burden, atmospheric stability, temperature and moisture profiles, and atmospheric water vapour, measured on a daily basis. Even though the atmospheric interactions of solar irradiance are well understood, a standardized product providing regular observations of global PAR is currently not available (Liang et al., 
2006), however, techniques to derive accurate estimates of global PAR using MODIS have been developed (Van Laake and Sanchez-Azofeifa, 2004; Liang et al. 2006).

\subsection{Absorbed photosynthetically active radiation}

Approaches to infer the fraction of PAR which is absorbed by the vegetation canopy using remote sensing techniques can be divided into empirical techniques, primarily relying on curve fitting of reflectance measurements and physical approaches, which attempt to model the relationship between leaf, canopy and stand-level biophysical characteristics and reflected and emitted radiation (Myneni and Williams, 1994; Hall et al., 1995) (Figure 2).

\subsubsection{Empirical determination of absorbed PAR}

Empirical approaches are largely based on spectral vegetation indices (SVI) which are linear and non-linear combinations of discrete spectral bands, seeking to maximize the sensitivity of the index to the canopy characteristic requested while minimizing the sensitivity to the unknown and unwanted canopy characteristics (Hall et al., 1995). Starting in the early 1980s, numerous studies have shown substantial evidence of a close relationship between $f_{P A R}$ and the top of the canopy reflectance measurements in the visible and near infrared region (Tucker 1979; Daughtry et al. 1983; Asrar et al. 1984), and theoretical work (Sellers, 1985; 1987) has given this relationship a solid basis as a measure of the solar photosynthetically active radiation absorbed by the canopy. Various linear and non-linear relationships between satellite-derived SVIs and 
$f_{\text {PAR }}$ have been found for different vegetation types and climatic conditions (e.g., Asrar et al., 1984; Badhwar et al., 1986; Fassnacht and Gower, 1997) with the most popular SVI being the Normalized Difference Vegetation Index (NDVI), defined as

$$
N D V I=\frac{\rho_{N I R}-\rho_{\text {Red }}}{\rho_{N I R}+\rho_{\text {Red }}}
$$

where $\rho_{\mathrm{NIR}}$ and $\rho_{\mathrm{Red}}$ is the reflectance in the near infrared and red, respectively (Tucker 1979). SVIs have also been used to follow seasonal dynamics of vegetation using temporal profile analysis (Badhwar and Henderson, 1981; Henderson and Badhwar, 1984), and, when seasonally integrated, have been shown to be correlated with aboveground net primary production (NPP, defined as the difference between GPP and plant respiration) on an annual basis (Goward and Dye, 1987; Waring et al., 2006).

While the body of evidence proving these relationships is impressive (Myneni and Williams, 1994), a direct conversion of satellite spectral reflectance to surface $f_{\text {PAR }}$ over larger areas is difficult, since empirical relationships are site and sampling condition dependant, sensor-specific, change in space and time and generally are unsuitable for application to large areas or in different phenological seasons (Goward and Huemmrich, 1992; Huemmrich and Goward, 1997; Gobron et al., 1997). Major factors influencing empirical estimates of $\mathrm{f}_{\mathrm{PAR}}$ using SVIs are vegetation spectral properties, pixel heterogeneity, background reflectance, solar zenith and view zenith angle, vegetation shadow fractions, atmospheric scattering and bidirectional reflectance effects ( $\mathrm{Li}$ and Strahler, 1985; Myneni and Williams, 1994). Some of these factors can be mitigated using more advanced indexing techniques such as the enhanced vegetation index (EVI) 
(Huete et al., 2002; 2006), which seek to enhance the vegetation signal with improved sensitivity in high biomass regions thereby de-coupling canopy background signals and reducing atmospheric influences, however, broad scaled direct application of vegetation indices remains challenging (e.g. Running and Nemani, 1988).

An empirical solution to the directional reflectance problem, resulting in the first globally available LAI and $f_{\text {PAR }}$ product as a monthly $1 \times 1^{\circ}$ dataset, was the FASIR (Fourier Adjusted, Solar zenith angle corrected, Interpolated and Reconstructed) approach of Sellers et al. (1994) and Los et al. (1994), based on data from the spaceborne Advanced Very High Resolution Radiometer (AVHRR) sensor (Tucker et al., 1986). FASIR accounts for the effects caused by varying illumination conditions using heuristic corrective methods to obtain spatially continuous multiyear datasets of surface variables, primarily for use in global climate models (Hall et al. 1995). Further (semiphysical) algorithms for the modeling of global LAI have also been reported by Price (1993).

\subsubsection{Physical models for determination of absorbed PAR}

Since the mid-1980's there has been an increase in the development of physical approaches to determining $f_{\mathrm{PAR}}$, due partly to global diagnostic studies using satellite data (Tucker and Sellers, 1986), plot scale field studies (Asrar et al., 1984; Tucker et al., 1981), large field experiments (Sellers et all., 1992; Hall et al, 1992; Sellers et al., 1997; Running et al., 1999) and theoretical work (Myneni et al, 1992; Hall et al, 1990; Sellers 1985; 1987; Sellers et al,. 1992; Sellers et al., 1996a,b). This research formed the basis 
for physical models of canopy reflectance, transferring reflectance and biophysical property relationships from the leaf level, where they can be easily measured and related to leaf composition and structure, to the pixel level, where leaf optics interact with canopy structure, understorey characteristics, background reflectance, view and illumination geometry to produce a complicated relationship among pixel-level reflectance, stand structural, biophysical and leaf optical properties (Hall et al., 1995). The understanding gained from these models is then used to develop algorithms to relate biophysical characteristics to reflectance measurements on the landscape and global levels (Hall et al., 1995). Modeling efforts that have addressed this problem are numerous, and can be placed into four general classes (Goel, 1988): 1) turbid medium models, describing the interaction of photons in the atmosphere-vegetation-soil medium (e.g. Myneni et al., 1997), 2) geometric optical models (e.g. Li and Strahler, 1985), 3) hybrid combinations of 1) and 2) (e.g. Li et al, 1995), and 4) complex computer simulation models (e.g. Goel et al., 1991). The model parameters either depend on physical properties directly (i.e. canopy structure and vegetation type) or can be obtained from mathematical inversion of reflectance measurements (e.g. Wanner et al., 1995), allowing the estimation of both leaf and canopy parameters in a predictive mode, thereby overcoming the need of parameterisation required for the use of regressive semi-empirical models (Privette et al., 1996, Bicheron and Leroy 1999). Over the last decade, models allowing for parameter acquisition from mathematical inversion have arisen as the most promising technique for retrieving $f_{P A R}$ (Meroni et al., 2004) and several studies have been successfully conducted for crop and forestred environments (e.g. Gao, 1994; Goel and Grier, 1988; Myneni et al., 1997). The accuracy of such 
estimations is dependent on the model employed, the type and quality of remote sensing data and the inversion procedure used (Jacquemoud et al., 2000).

One of the most prominent examples of a radiative transfer based global $f_{P A R}$ model is the LAI/f $f_{\text {PAR }}$ product used in MODIS, providing 8-day averaged global LAI and $f_{\text {PAR }}$ data at a $1 \times 1 \mathrm{~km}$ spatial resolution. The algorithm uses photon transport theory to estimate both the radiation regime within the vegetation canopy and the radiant exitance, based on the architecture of individual plants and the entire canopy, optical properties of vegetation elements and soil atmospheric conditions (Knyazikhin, 1999; Myneni et al. 1989). The MODIS algorithm requires a land cover classification (also derived from MODIS data) to model the radiative transfer over larger areas. Canopy transmittance, reflectance, and absorptance are elements of a look-up table (LUT), distinguishing between biome types, each of which represents a pattern of the architecture of an individual tree (leaf normal orientation, stem-trunk-branch area fractions, leaf and crown size) and the entire canopy (trunk distribution, topography), as well as patterns of spectral reflectance and transmittance of other vegetation elements. Soil type and understorey are also biome specific, and can vary continuously within given biomedependent ranges. Information on the leaf canopy spectral properties from MODIS and structural attributes from the LUT are then used to retrieve LAI and f $f_{\text {AR }}$ (Knyazikhin et al. 2003). A full description of the MODIS $f_{P A R}$ LAI product can be obtained from Knyazikhin et al. (1998; 2003), reviewed by Myneni et al., (2002).

\subsection{Photosynthetic light use efficiency}


Whilst determination of $f_{\text {PAR }}$ has matured over a number of years, the estimation of $\varepsilon$ using remote sensing techniques increased only in the past decade, encouraged by the advent of fine resolution spectral measurement devices allowing tracking of subtle changes in canopy reflectance using narrow wavebands in the visible and near infrared region. In general, approaches inferring $\varepsilon$ from remote sensing can be classified into either indirect techniques, seeking to determine $\varepsilon$ from environmental stresses, or direct approaches, trying to predict $\underline{\varepsilon}$ by measuring changes in leaf spectral reflectance resulting from photoprotection and chlorophyll fluorescence (Figure 2).

\subsubsection{Determination of photosynthetic efficiency from environmental stresses}

Stress factors driving photosynthetic efficiency are numerous and their detection over larger areas is relatively difficult due to the high temporal and spatial variability inherent to site and meteorological conditions. Remote sensing of stresses has mostly focussed on water, nitrogen and temperature related conditions. While more severe stresses, manifesting in symptoms such as chlorosis, defoliation or degradation of canopies, can be sensed using time series of broad band SVIs based on reflectance in the visible and near infrared region (Liu and Kogan, 1996), these stresses are exceptional and such techniques cannot be applied to sense more moderate stress situations where the plants' response is much less apparent (Baret et al., 2007).

Remote sensing of soil moisture related stress factors includes passive microwave systems (e.g. Prevot et al, 2003; Wigneron et al., 2003) and combinations of simultaneous measurements in the visible, near infrared, and thermal infrared radiation. 
While microwave systems have shown good correspondence to soil moisture content, existing instruments lack adequate spatial and temporal resolution for sufficiently detailed estimates of water related vegetation stresses (Deshayes et al., 2006). Spectral measurements, combining SVI based estimates of the vegetation status with thermal radiation (so called temperature vegetation index - TVX (Prihodko and Goward, 1997)) predict soil moisture content from the difference between soil temperature and vegetation canopy temperature. This technique has been successfully used to determining plant water deficit (Lopez et al., 1991), water balance (Duchemin et al., 1999), and latent heat fluxes (Vidal et al., 1994) on local scales, however, application over larger areas remains complex (Prince and Goward, 1996), as 1) the difference between soil temperature and vegetation canopy temperature is not only a function of soil moisture but is also dependent on the incident solar radiation load and 2) the moisture content of sub-surface layers cannot be determined using this technique (Prince and Goward, 1995).

Like soil water related stresses, the understanding of nitrogen cycling and nitrification in forest ecosystems has greatly improved over recent decades, however the ability to characterize spatial patterns using remote sensing is limited (Ollinger et al., 2002) as derivation of stress maps is complex (Guerif and Duke, 2000). Early studies on the use of remote sensing for nitrogen stress quantification were based on empirical relationships using SVIs sensitive to the leaf chlorophyll content (Peñuelas et al., 1994; Bausch and Duke, 1996). More recent approaches suggest the use of hyperspectral imagery for direct prediction of foliage nitrogen content from narrow waveband reflectance (Wessman et al. 1988, Martin and Aber 1997). Ollinger et al. (2002) 
presented a method to derive foliage nitrogen using data from NASA's Airborne Visible and Infra-Red Imaging Spectrometer (AVIRIS). A first study successfully applying spaceborne instrumentation was reported by Smith et al. (2003) using EO1-Hyperion satellite data. While the results from these hyperspectral approaches are encouraging, application over larger areas presents challenges to data analysis (Liu et al., 2006), as narrow waveband reflectance measurements are highly sensitive to atmospheric scattering and directional reflectance effects.

Arguably, the first stress based model for prediction of global $\underline{\varepsilon}$ was the Global Production Efficiency Model (GLO-PEM) of Prince and Goward (1995) based on the AVHRR Land Pathfinder dataset providing 10 day averages of daily global observations. GLO-PEM uses a TVX based approach to estimate water related stresses for a normalized solar zenith angle (Goward and Prince 1995; Nemani and Running, 1989). Estimates of atmospheric saturation deficit $(\underline{D})$ are modeled from combinations of air temperature and atmospheric water vapour, derived from thermal infrared observations in two different wavebands. A similar approach of a global model predicting primary production was presented by Field et al., 1995 which uses estimates of $\varepsilon$ based on the CASA model (Carnegie Ames Stanford Approach) introduced by Potter et al., 1993; calibrated using AVHRR data.

More recently, global estimation of $\underline{\varepsilon}$ from environmental stresses is undertaken using the MODIS GPP product (MOD17), which estimates GPP from 8-day averages of $f_{P A R}$, PAR and $\varepsilon$ (Heinsch et al., 2002). The MOD17 algorithm models $\underline{\varepsilon}$ using a look-up table containing biome specific information about the maximum light use efficiency $\underline{\underline{m} \max }$, daily minimum temperature $\left(\underline{T}_{\operatorname{Min}}\right)$ and $\underline{D}$ for maximum and minimum $\underline{\varepsilon}$ of each biome type 
(Running et al. 2000; Turner et al. 2003a). The biome specific constant $\underline{\varepsilon}_{\max }$ is adjusted using $1^{\circ} \times 1.25^{\circ}$ estimates of $\underline{I}_{\text {Min }}$ and $\underline{D}$, derived from GCMs (e.g. Potter et al., 1993; Sellers et al., 1996a, 1996b) to account for the limiting effects of climatic variables on $\underline{\varepsilon}$ (Heinsch et al., 2002; Turner et al., 2003a),

$$
\varepsilon=\varepsilon_{\max } \times T_{\text {Min }} \times D
$$

For a full description of the MODIS GPP algorithm see Heinsch et al. (2002).

\subsubsection{Direct estimation of photosynthetic efficiency}

Thus far estimation of $\underline{\varepsilon}$ has been via environmental stresses. In the past decade research has focussed on the direct estimation of $\underline{\varepsilon}$, as this technique not only offers the potential to determining the combined effect of vegetation stresses, but also includes information about the degree to which these stresses are limiting photosynthesis (Adams and Demmig-Adams, 1996).

Remote estimation of chlorophyll fluorescence includes both passive (Carter et al., 1990) and laser-induced active methods (Rosema et al., 1998; Corp et al., 2006). Active fluorescence measurements use laser pulses to manipulate the level of photosynthetic activity and to measure the corresponding changes in the chlorophyll fluorescence yield (e.g. Kolber et al., 2005). These pulse-modulated measuring systems, probe the yield of chlorophyll fluorescence under steady-state illumination $(\underline{F s})$ and during a short saturating flash delivered at close range $(1-100 \mathrm{~mm})$, and have been successfully used for measuring photosynthesis (Adams et al., 1999; Rascher et al., 2000). However, their 
application is mostly restricted to individual leaves in accessible canopies (Ananyev et al., 2005), with a few notable exceptions (e.g. Cecchi et al., 1994).

Evidence of a solar induced fluorescence signal superimposed on leaf reflectance signatures has been reported by various studies (Buschmann and Lichtenthaler, 1977; 1999; Peñuelas et al., 1995; Gitelson et al. 1999) and the effects of solar induced chlorophyll flurorescence emissions on the apparent spectral reflectance have been investigated using radiative transfer modeling (Zarco-Tejada et al., 2000). Chlorophyll fluorescence from passive remote sensing systems provides a potential for broad scaled assessment of $\underline{\varepsilon}$ (Corp et al., 2006), however, its application is technically challenging as under natural sunlight illumination chlorophyll fluorescence emitted by the vegetation represents less than $3 \%$ of the reflected light in the near infrared part of the electromagnetic spectrum (Moya et al., 2004). Consequently, passive sensing of chlorophyll fluorescence is possible only using sub-nanometer reflectance bands in the red and near infrared regions (often 690 and $760 \mathrm{~nm}$ ) where solar radiation is not abundant as a result atmospheric absorption (so called Fraunhofer lines) (Meroni and Colombo, 2006). The intended launch of a spaceborne fluorescence sensor by the European Space Agency (ESA) as part the FLEX (fluorescence experiment) mission may provide new opportunities to exploit this method for estimation of global $\varepsilon$ from space.

Determing $\varepsilon$ using the photoprotective mechanism in leaves is based on observation of changes in leaf spectral reflectance resulting from the epoxidation state of the xanthophyll cycle. These changes manifest in two narrow waveband absorption features 
at 505 and at $531 \mathrm{~nm}$ and can be quantified using SVIs, such as the Photochemical Reflectance Index (PRI), defined as (Gamon et al., 1990),

$$
P R I=\frac{\rho_{531}-\rho_{570}}{\rho_{531}+\rho_{570}}
$$

comparing the reflectance at $531 \mathrm{~nm}\left(\underline{\varrho_{531}}\right)$ to a xanthophyll-insensitive reference band at $570 \mathrm{~nm}(\underline{570})$. Originally established for sunflower leaves, the empirical relationship between PRI and $\varepsilon$ has been confirmed over a wide range of species (Peñuelas et al., 1994; 1995; Filella et al., 1996; Gamon and Surfus, 1999) thereby demonstrating the potential use of this method for global estimation of $\underline{\varepsilon}$. Upscaling of these findings from leaf to canopy, regional and global levels, however remains challenging. First, the temporal dynamics existing in plant photosynthesis, require the observation of vegetation status under multiple illumination and viewing conditions and these observations are then, even more than in the case of $f_{P A R}$, subject to bidirectional reflectance and scattering effects (Los et al., 2005) overlapping with the desired reflectance signal (Huemmrich et al., 2005). Second, airborne or spaceborne sensors can only provide snapshots in time determined by a given aircraft or satellite overpass (Sims et al., 2005), however, the temporal and spatial requirements for these observations to be representative of the physiological status of plant canopies are not well understood (Hall et al., 1995). Third, the relationship between PRI and $\underline{\varepsilon}$ is species dependent and also changes with age, canopy structure, disturbances and LAl (Rahman et al., 2001), making a spatial extrapolation of empirical findings difficult. 
Recent efforts to further the understanding of the temporal and spatial dynamics involved, include near surface observations using transect measurements (Sims et al., 2006), permanently established tower based observations of forest canopies (Leuning et al., 2006; Hilker et al., 2007), and airborne measurements (Nichol et al., 2000; 2002; Chen and Vierling, 2006; Rahman et al., 2001). A first spaceborne assessment of $\varepsilon$ was introduced by Drolet et al. (2005), successfully using backscatter reflectance data from MODIS Aqua over the Canadian boreal forest with a spatial resolution of $1 \mathrm{~km}^{2}$. 


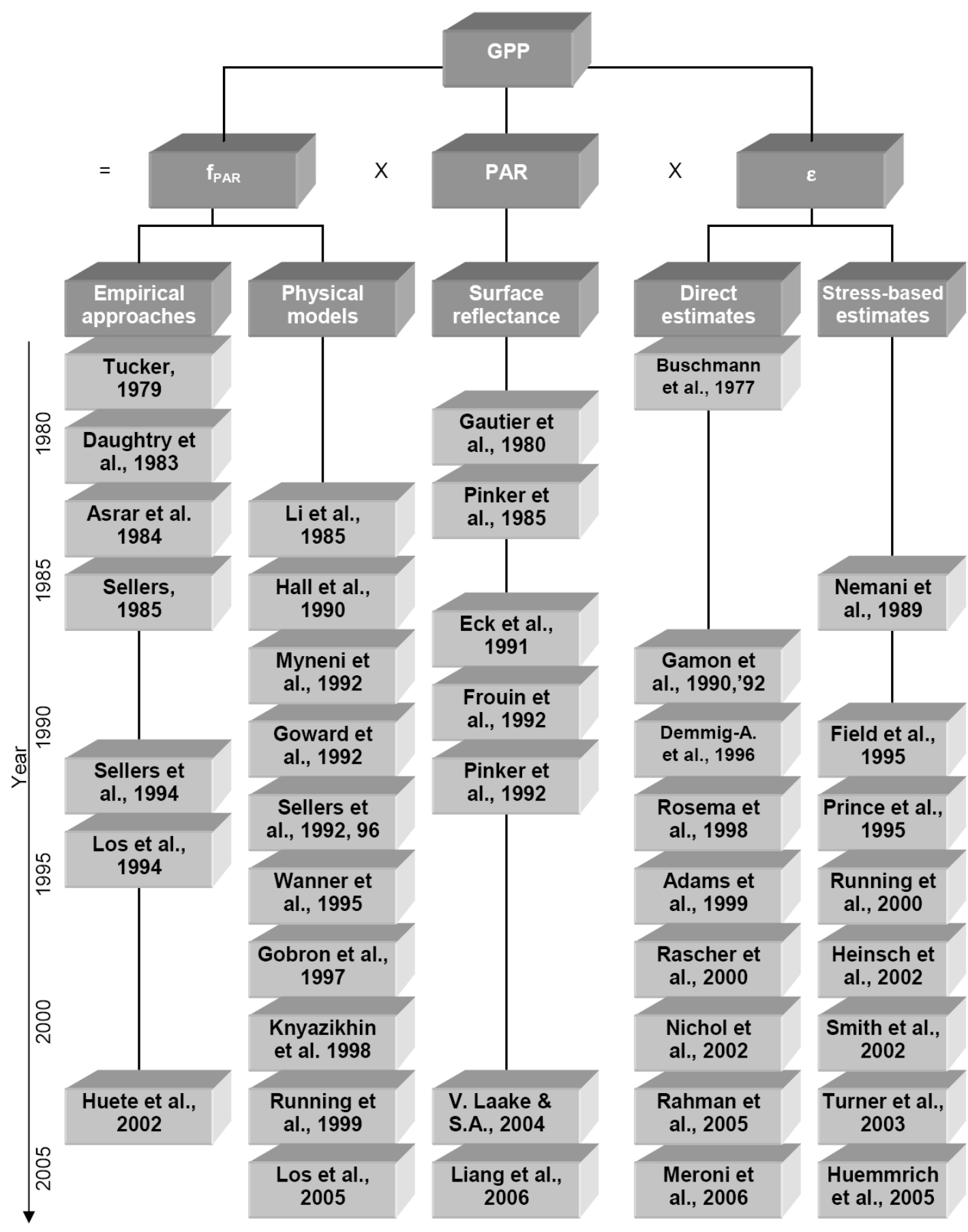

Figure 2: Illustration of approaches to assess GPP from remote sensing. PAR is generally derived from Top of Atmosphere (TOA) reflectance, techniques inferring $f_{P A R}$ from remote sensing can be divided into empirical empirical approaches and physical models. $\varepsilon$ can either be determined directly or indirectly through stress factors. Some examples of key literature to each approach are given. 


\section{Validation approaches}

Validation and operationalization of the light use efficiency approach is currently underway at a number of spatial and temporal scales. At the stand level, eddy covariance data (EC) exhibit a key role for studying the temporal and spatial variability of GPP (Turner et al., 2006). EC measurements facilitate continuous estimates of net carbon accumulation, also referred to as net ecosystem production (NEP), from flux towers measuring $\mathrm{CO}_{2}$ mixing ratios of up and down-moving eddies (Baldocchi, 2003), thereby using the covariance between the vertical velocity $(\underline{w})$ and the mole-mixing ratio of $\mathrm{CO}_{2}(\underline{\mathrm{s}})$ to estimate carbon fluxes $\left(\underline{\mathrm{F}}_{\mathrm{c}}\right)$,

$$
F_{C}=\overline{\rho_{a}} \overline{w^{\prime} s_{c}^{\prime}}
$$

where $\bar{\rho}_{a}$ is the mean molar density of dry air and $\overline{w^{\prime} s_{c}^{\prime}}$ is the covariance between the vertical velocity $(\underline{\mathrm{w}})$ and the mole-mixing ratio of $\mathrm{CO}_{2}\left(\underline{\mathrm{s}}_{\mathrm{c}}\right)$. The spatial scale of an EC flux tower is about $1 \mathrm{~km}^{2}$ (Kljun et al. 2004) and the temporal resolution is given by the integration of high frequency data, usually at a half hourly basis (Morgenstern et al., 2004). GPP can be determined from EC data by adding estimates of ecosystem respiration $(\underline{R})$ to measured NEP values, and $\varepsilon$ can be obtained from additional measurements of $\mathrm{f}_{\mathrm{PAR}}$ and PAR using radiation sensors above and below the canopy (Humphreys et al., 2006). Remotely sensed estimates of stand level GPP have been correlated with EC flux data from ground based (Cheng et al., 2006; Sims et al., 2006), tower based (Filella et al., 1996; Stylinski et al., 2002), airborne (Nichol et al., 2000; 2002) and spaceborne platforms (Running et al., 1999; Drolet et al., 2005; Coops et al., 2007). Also, to bridge the spatial gap existing between near surface and airborne 
remote sensing platforms, Chen and Vierling (2006) tested a tethered balloon mounted platform to evaluate canopy reflectance of a grassland conifer forest ecotone. Networking approaches, such as the recently established SpecNet initiative (Gamon et al., 2006) attempt to link these observations with existing global fluxtower sites to further the understanding of relationships existing between biophysical processes and spectral reflectance data, thereby trying to overcome the fundamental scale mismatch between estimates obtained from eddy flux and remote sensing (Running et al., 1999; Rahman et al. 2001; Cheng et al. 2006; Gamon et al., 2006). Other objectives of this network are the exploration of temporal matters, derivation of flux components and the validation of satellite data products (Gamon et al., 2006).

At the landscape level, verification of GPP estimates has been undertaken in various broad scaled field studies comparing ground based estimates to remotely sensed data. One of the first projects designed to coordinate data collected by satellites, aircraft, and ground instruments in order to improve the understanding of carbon and water cycles, was FIFE (First ISLSCP (International Satellite Land Surface Climatology Project) Field Experiment), undertaken in the prairies of central Kansas from 1987 through 1989 (e.g. Hall et al., 1991; 1992; Sellers and Hall., 1992; Walthall, et al., 1993). The objectives of FIFE were to improve the understanding of interactions between the atmosphere and the vegetated land surface and to investigate the use of satellite observations to infer climatologically significant land surface parameters (Sellers and Hall., 1992). While remotely sensed estimates of $f_{P A R}$ were found to be accurate within a range of $10 \%$, key issues identified for remote sensing of photosynthesis were stress related factors such 
as soil moisture and saturation deficit (Hall et al., 1992; Charpentier and Groffman, 1992).

One of the largest projects aiming to improve our understanding of terrestrial carbon cycling and other biosphere-atmosphere interactions was the Boreal-EcosystemAtmosphere Study (BOREAS), undertaken between 1993 and 1997. Specifically designed to bridge a wide range of spatial scales (e.g. Kharouk et al., 1995; Sellers et al., 1995; 1997; Potter et al., 1999; Goetz et al., 1999), BOREAS integrated repeated leaf scale, flux-tower, airborne, and spaceborne observations to investigate issues of up-scaling local observations to landscape levels (1000x1000km) (Sellers et al., 1997). The study, located at multiple boreal forest sites in Saskatchewan and Manitoba (Canada), substantially improved the use of remote sensing for definition of vegetation structure and land cover for assessment of the surface-atmosphere exchange of mass and energy, nature and variability of surface albedo and radiation budgets, and the regional carbon balance (Gamon et al., 2004).

Most recently, validation of the MODIS GPP product was undertaken using the BigFoot approach, scaling field observations to global, satellite based estimates of GPP. BigFoot relied on ground measurements, EC-flux tower data, remote sensing data, and ecosystem process models to represent $\mathrm{CO}_{2}$ fluxes for different biome types. Nine BigFoot study sites spanned eight major biomes, from desert to tundra, to tropical forest (Running et al., 1999). Validation of the MODIS GPP product was mainly undertaken in form of time series comparisons between GPP estimated from eddy covariance flux tower data and GPP from MODIS for one or more $1-\mathrm{km}^{2}$ cells surrounding the tower (Turner et al., 2003a,b; Xiao et al., 2004). While some of these comparisons have 
shown reasonable agreement between tower based estimates of $\mathrm{CO}_{2}$ fluxes and MODIS land cover products, also numerous limitations were found and issues identified for further research: The largest error associated with the land cover classification is the simplifying assumption that each $1 \times 1 \mathrm{~km}$ pixel only contains a single land cover class (Heinsch et al., 2006). This assumption generally fails to reflect the spatial heterogeneity in land cover, stand age, soil type and canopy structure for most biomes (Goulden et al., 1996). The use of a simple lookup table approach to determining $\varepsilon$ from biome-specific parameters which do not vary in space and time (Running et al., 2000; Heinsch et al., 2002; Turner et al., 2003a), and distinguish only between 11 different vegetation types (Turner et al., 2003a; Heinsch et al., 2006) has been identified as the weak point of the GPP product as it greatly simplifies the existing spatial and temporal variability in $\underline{\varepsilon}$. In addition, assigning values of $\underline{\varepsilon}$ on the basis of biome type assumes between-biome variability to be greater than within biome variability, which is often not realistic (Goetz and Prince, 1996; Landsberg et al., 1997). A further serious limitation is the degree to which the GCM derived inputs represent realistic estimates of climate variables because of the coarse scale of the GCM model outputs $(\sim 100 \mathrm{~km})$ (Turner et al., 2003a,b). These issues, together with errors related to propagation from other underlying MODIS products (Heinsch et al., 2006), have been identified as potential sources of the differences found between satellite-based GPP estimates and field measurements for some biomes (Running et al., 1999; Coops et al., 2007). 


\section{Requirements and direction for future studies}

The ability to acquire primary production from remotely sensed data has increased considerably over the last few decades. However, from the reviewed literature, it is apparent that accurate modeling of GPP over large areas remains an active area of research with issues remaining to be solved on the leaf, stand, and landscape level.

\subsection{Leaf level}

Arguably, the use of remote sensing to detecting photosynthesis at the leaf level is relatively established, however many gaps remain our in understanding of the biochemical mechanisms that invoke and relax photo-protection and chlorophyll fluorescence. To date, an energy dependent component, likely induced by low $\mathrm{pH}$ values in the thylakoid membrane of the chloroplast (Demmig-Adams and Adams, 1996) and an energy independent component, relaxing only very slowly after more severe stress situations such as droughts or winter stress, have been identified (Adams et al., 1999). While the energy dependent component is reasonably well understood, less is known about the processes driving the energy independent component (Demmig and Winter, 1988). Additionally, the role of the Lutein cycle (Bungard et al., 1999) in photosynthetic efficiency is largely unexplored. Comprehensive understanding of these biochemical mechanisms driving the photochemical reaction process across a wide range of species is a key requirement for upscaling leaf level estimates to stand and global levels. 


\subsection{Stand level}

At the stand level, uncertainty remains in understanding the temporal dynamics involved in photosynthetic efficiency and the contributions of shaded and sunlit parts of the canopy (Demmig-Adams et al., 1998). To improve the understanding of stand level GPP, modeling requires observation of vegetation canopies in a continuous mode and under varying illumination and environmental conditions. Accurate algorithms are required to distinguish the reflectance signals obtained from such observations between physiologically and physically induced components. The application of bi-directional reflectance distribution functions (BRDF)(e.g. Wanner et al., 1995; Li and Strahler, 1995) can help in this regard. Separation of reflectance signals however, is not trivial, as the high physiologically induced variability in canopy reflectance especially with respect to $\underline{\varepsilon}$ makes acquisition of BRDF-parameters from inversion of semi-empirical algorithms difficult (Los et al., 2005).

Possible ways to address these issues include spectral measurements from permanently established, near surface remote sensing devices, facilitating intensive and continuous studies of canopy level reflectance. At present, relatively few spectral datasets have been acquired using radiometers mounted on canopy cranes (Mariscal et al., 2004) or towers (Leuning et al., 2006; Hilker et al., 2007). Future research would benefit from integrated, tower based approaches to intensify measures of reflectance properties and temporal variability of GPP at networked sites, which can then be linked directly to $\mathrm{CO}_{2}$ fluxes determined using the eddy covariance technique. Based on physical reflectance properties studied on the stand level using near surface remote sensing, mathematical models can be developed which, when calibrated from high 
resolution satellite platforms on a daily and fully spatially basis, may facilitate detailed estimates of photosynthetic flux from space. Hence, the success for estimating carbon fluxes at broader levels will heavily depend on our understanding of the dynamics and interrelations of spectral reflectance obtained at the stand scale.

\subsection{Landscape level}

At the landscape scale, research focused on the complex interactions between the biosphere and atmosphere targeting issues of upscaling from site observations to ecoregion, biome, and global levels is underway and must be actively pursued, with major challenges evident in the areas of modelling and minimising signal distortions, due to both the atmosphere and directional reflectance effects. Our understanding of bidirectional reflectance, radiative transfer modeling, and interactions between reflectance and forest stand structure has benefited greatly from multi-angle instruments, including the POLDER (Polarization and Directionality of Earth Reflectance) (Deschamps et al., 1994) and MISR (Multi-angle Imaging Spectrometer) (e.g. Lyapustin et al., 2007) sensors, specifically designed to address BRDF characteristics of the Earth surface from space (Leroy et al. 1997; Gamon et al., 2006). However, several challenges related to atmospheric effects remain, primarily caused by water vapor and aerosols, as these, even though they are well understood, are difficult to correct due to their high temporal and spatial variability (Hall et al., 1995).

Direct approaches regarding global prediction of $\underline{\varepsilon}$ from remote sensing, using both xanthophyll related pigment changes in the visible spectrum and fluorescence 
measurements in the near infrared region show promise to facilitate precise estimation of $\underline{\varepsilon}$ over large areas thereby overcoming a number of issues related to indirect approaches using stress related factors. Global estimation of vegetation stresses, however, provides valuable information that can help understanding the physiological responses of plant canopies observed. Satellite sensors providing high spectral and spatial resolution hold promise to facilitate acquisition of detailed stress maps of plant canopies which will allow mutual validation of $\underline{\varepsilon}$ acquired from direct and indirect approaches in a spatially comprehensive mode.

Currently there is an absence of spaceborne sensors available with wavebands narrow enough to obtain reflectance measurements specifically in the PRI region. EO1Hyperion was the first hyperspectral sensor in space with a contiguous spectral bandwidth of $10 \mathrm{~nm}$. However, being designed as a demonstration instrument, this sensor is limited in its signal to noise ratio and calibration accuracy (Datt et al., 2003; Khurshid et al., 2006). The MODIS sensor, such as on AQUA, provides wavebands close to the PRI region (Drolet et al., 2005), however, initial results indicate that the approach at this stage does not sufficiently account for the spatial heterogeneity of the landscape. Additionally, there is a lack of algorithms available for processing the full suite of MODIS Aqua spectral bands over land surfaces which limits the routine application of the approach. Future generation satellite sensors, data processing streams, and resultant data products can combine to help address and eventually overcome these issues.

The large area characterization of primary production depends on comprehensive testing and continued efforts of land surface validation, requiring coordinated scientific 
networking to meaningfully combine findings and results representative of a range of spatial scales. Networking approaches such as the Fluxnet community have greatly improved our knowledge on interactions of plant physiological responses to changing environmental conditions in the past. Intensified and networked research efforts are required for improved understanding of physically and physiologically induced reflectance properties of various vegetation types to facilitate modeling of GPP estimates representative of large areas. The ability to characterize GPP over a range of scales will greatly benefit from interdisciplinary communication and networking for both development of algorithms and product validation. 


\section{Acknowledgements}

The anonymous reviewers are thanked for helpful insights and constructive comments

on the manuscript. This research is partially funded by a DAAD postgraduate scholarship to Hilker and a NSERC Discovery grant to Coops. 


\section{References}

Adams WW, Demmig-Adams B, Logan BA, Barker DH, Osmond CB. Rapid Changes in Xanthophyll Cycle-Dependent Energy Dissipation and Photosystem II Efficiency in Two Vines, Stephania Japonica and Smilax Australis, Growing in the Understory of an Open Eucalyptus Forest. Plant Cell and Environment 1999; 22(2):125-36.

Ananyev G, Kolber ZS, Klimov D Falkowski PG, Berry JA, Rascher U, Martin R, Osmond B. Remote Sensing of Heterogeneity in Photosynthetic Efficiency, Electron Transport and Dissipation of Excess Light in Populus Deltoides Stands Under Ambient and Elevated Co2 Concentrations, and in a Tropical Forest Canopy, Using a New Laser-Induced Fluorescence Transient Device. Global Change Biology 2005; 11(8):1195-206.

Asrar G, Fuchs M, Kanemasu ET, Hatfield JL. Estimating Absorbed Photosynthetic Radiation and Leaf-Area Index From Spectral Reflectance in Wheat. Agronomy Journal 1984; 76(2):300-6.

Badhwar GD, Henderson KE. Estimating Development Stages of Corn From Spectral Data - an Initial Model. Agronomy Journal 1981; 73(4):748-55.

Badhwar GD, Macdonald RB, Mehta NC. Satellite-Derived Leaf-Area-Index and Vegetation Maps as Input to Global Carbon-Cycle Models - a Hierarchical Approach. International Journal of Remote Sensing 1986; 7(2):265-81.

Baker KS, Frouin R. Relation Between Photosynthetically Available Radiation and Total Insolation at the Ocean Surface Under Clear Skies. Limnology and Oceanography 1987; 32(6):1370-7.

Baldocchi DD. Assessing the Eddy Covariance Technique for Evaluating Carbon Dioxide Exchange Rates of Ecosystems: Past, Present and Future. Global Change Biology 2003; 9(4):479-92.

Baret F, Houles V, Guerif M. Quantification of Plant Stress Using Remote Sensing Observations and Crop Models: the Case of Nitrogen Management. Journal of Experimental Botany 2007; 58(4):869-80.

Bausch WC, Duke HR. Remote Sensing of Plant Nitrogen Status in Corn. Transactions of the ASAE 1996; 39(5):1869-75.

Bicheron P, Leroy M. A Method of Biophysical Parameter Retrieval at Global Scale by Inversion of a Vegetation Reflectance Model. Remote Sensing of Environment 1999; 67(3):251-66.

Bilger W, Björkman O, Thayer SS. Light-Induced Spectral Absorbance Changes in Relation to Photosynthesis and the Epoxidation State of Xanthophyll Cycle Components in Cotton Leaves. Plant Physiology 1989; 91(2):542-51. 
Bilger W, Björkman O. Role of the Xanthophyll Cycle in Photoprotection Elucidated by Measurements of Light-Induced Absorbency Changes, Fluorescence and Photosynthesis in Leaves of Hedera-Canariensis. Photosynthesis Research 1990; 25(3):173-85.

Blackburn WJ, Proctor JTA. Estimating Photosynthetically Active Radiation From Measured Solar Irradiance. Solar Energy 1983; 31(2):233-4.

Bland WL, Clayton MK. Spatial Structure of Solar-Radiation in Wisconsin. Agricultural and Forest Meteorology 1994; 69(1-2):75-84.

Bland WL. Uncertainty of Daily Insolation Estimates From a Mesoscale Pyranometer Network. Journal of Atmospheric and Oceanic Technology 1996; 13(1):255-261.

Bungard RA, Ruban AV, Hibberd JM, Press MC, Horton P, Scholes JD. Unusual Carotenoid Composition and a New Type of Xanthophyll Cycle in Plants. Proceedings of the National Academie of Science USA 1999; 96(3):1135-1139.

Buschmann C, Lichtenthaler HK. Contribution of Chlorophyll Fluorescence to the Reflectance of Leaves in Stressed Plants as Determined With the VirafSpectrometer. Zeitschrift Für Naturforschung C-a Journal of Biosciences 1999; 54(9-10):849-855.

Buschmann C, Lichtenthaler HK. Hill-Activity and P700 Concentration of Chloroplasts Isolated From Radish Seedlings Treated With Beta-Indoleacetic Acid, Kinetin or Gibberellic-Acid. Zeitschrift Für Naturforschung C-a Journal of Biosciences 1977; 32(9-10):798-802.

Carter CD, King GB, Laurendeau NM. Laser-Induced Fluorescence Measurements of Oh in Laminar C2h6/O-2/N-2 Flames at High-Pressure. Combustion Science and Technology 1990; 71(4-6):263-273.

Cecchi G, Mazzinghi P, Pantani L, Valentini R, Tirelli D, Deangelis P. Remote-Sensing of Chlorophyll-a Fluorescence of Vegetation Canopies .1. Near and Far-Field Measurement Techniques. Remote Sensing of Environment 1994; 47(1):18-28.

Charpentier MA, Groffman PM. Soil-Moisture Variability Within Remote-Sensing Pixels. Journal of Geophysical Research-Atmospheres 1992; 97(D17):18987-18995.

Chen JM, Black TA. Defining Leaf-Area Index for Non-Flat Leaves. Plant Cell and Environment 1992; 15(4):421-429.

Chen JM. Canopy Architecture and Remote Sensing of the Fraction of Photosynthetically Active Radiation Absorbed by Boreal Conifer Forests. IEEE Transactions on Geoscience and Remote Sensing 1996; 34(6):1353-1368.

Chen XX, Vierling L. Spectral Mixture Analyses of Hyperspectral Data Acquired Using a Tethered Balloon. Remote Sensing of Environment 2006; 103(3):338-350. 
Cheng YF, Gamon JA, Fuentes DA, Mao ZY, Sims DA, Qui HL, Claudio H, Huete A, Rahman AF. A Multi-Scale Analysis of Dynamic Optical Signals in a Southern California Chaparral Ecosystem: a Comparison of Field, AVIRIS and MODIS Data. Remote Sensing of Environment 2006; 103(3):369-378.

Comins HN, McMurtrie RE. Long-Term Response of Nutrient-Limited Forests to Co2 Enrichment - Equilibrium Behavior of Plant-Soil Models. Ecological Applications 1993; 3(4):666-681.

Coops, NC, Black, TA, Jassal, RS, Trofymow, JA, Morgenstern, K. Comparison of MODIS, eddy covariance determined and physiologically modeled gross primary production (GPP) in a Douglas-fir forest stand. Remote Sensing of Environment, 2007; 107:385-401.

Corp LA, Middleton EM, Mcmurtrey JE, Campbell PKE, Butcher LM. Fluorescence Sensing Techniques for Vegetation Assessment. Applied Optics 2006; 45(5):1023-1033.

Datt B, Mcvicar TR, Van Niel TG, Jupp DLB, Pearlman JS. Preprocessing Eo-1 Hyperion Hyperspectral Data to Support the Application of Agricultural Indexes. IEEE Transactions on Geoscience and Remote Sensing 2003; 41(6):1246-1259.

Daughtry CST, Gallo KP, Bauer ME. Spectral Estimates of Solar-Radiation Intercepted by Corn Canopies. Agronomy Journal 1983; 75(3):527-531.

Dawson TP, North PRJ, Plummer SE, Curran PJ. Forest Ecosystem Chlorophyll Content: Implications for Remotely Sensed Estimates of Net Primary Productivity. International Journal of Remote Sensing 2003; 24(3):611-617.

Demmig B, Winter K. Characterization of 3 Components of Non-Photochemical Fluorescence Quenching and Their Response to Photoinhibition. Australian Journal of Plant Physiology 1988; 15(1-2):163-77.

Demmig-Adams B, Adams WW. Photosynthesis - Harvesting Sunlight Safely. Nature 2000; 403(6768):371-374.

Demmig-Adams B, Adams WW. The Role of Xanthophyll Cycle Carotenoids in the Protection of Photosynthesis. Trends in Plant Science 1996; 1(1):21-26.

Demmig-Adams B, Moeller DL, Logan BA, Adams WW. Positive Correlation Between Levels of Retained Zeaxanthin Plus Antheraxanthin and Degree of Photoinhibition in Shade Leaves of Schefflera Arboricola (Hayata) Merrill. Planta 1998; 205(3):367-374.

Demmig-Adams B. Carotenoids and Photoprotection in Plants - a Role for the Xanthophyll Zeaxanthin. Biochim Biophys Acta 1990; 1020(1):1-24. 
Deschamps PY, Breon FM, Leroy M, Podaire A, Bricaud A, Buriez JC, Seze G. The POLDER Mission - Instrument Characteristics and Scientific Objectives. IEEE Transactions on Geoscience and Remote Sensing 1994; 32(3):598-615.

Deshayes M, Guyon D, Jeanjean H, Stach N, Jolly A, Hagolle O. The Contribution of Remote Sensing to the Assessment of Drought Effects in Forest Ecosystems. Annals of Forest Science 2006; 63(6):579-95.

Drolet GG, Huemmrich KF, Hall FG, Middleton EM, Black TA, Barr AG, Margolis HA. A MODIS-Derived Photochemical Reflectance Index to Detect Inter-Annual Variations in the Photosynthetic Light-Use Efficiency of a Boreal Deciduous Forest. Remote Sensing of Environment 2005; 98(2-3):212-224.

Duchemin B, Guyon D, Lagouarde JP. Potential and Limits of NOAA-AVHRR Temporal Composite Data for Phenology and Water Stress Monitoring of Temperate Forest Ecosystems. International Journal of Remote Sensing 1999; 20(5):895-917.

Eck TF, Dye DG. Satellite Estimation of Incident Photosynthetically Active Radiation Using Ultraviolet Reflectance. Remote Sensing of Environment 1991; 38(2):135146.

Fassnacht KS, Gower ST. Interrelationships Among the Edaphic and Stand Characteristics, Leaf Area Index, and Aboveground Net Primary Production of Upland Forest Ecosystems in North Central Wisconsin. Canadian Journal of Forest Research-Revue Canadienne De Recherche Forestière 1997; 27(7):10581067.

Field C., Mooney HA. The photosynthesis-nitrogen relationship in wild plants. In: T.Givnish, editor. On the Economy of Plant Form and Function. Cambridge Univ. Press, Cambridge, U.K. 1986; 22-55.

Field CB, Jackson RB, Mooney HA. Stomatal Responses to Increased Co2 Implications From the Plant to the Global-Scale. Plant Cell and Environment 1995; 18(10):1214-1225.

Field CB. Ecological scaling of carbon gain to stress and resource availability. In: Integrated Responses of Plants to Stress (eds. Mooney, HA Winner, SE Pell, EJ). Academic Press, San Diego, CA. 1991; 35-65.

Filella I, Amaro T, Araus JL, Peñuelas J. Relationship Between Photosynthetic Radiation-Use Efficiency of Barley Canopies and the Photochemical Reflectance Index (PRI). Physiologia Plantarum 1996; 96(2):211-216.

Frouin R, Pinker RT. Estimating Photosynthetically Active Radiation (PAR) at the Earths Surface From Satellite-Observations. Remote Sensing of Environment 1995; 51(1):98-107. 
Gamon JA, Field CB, Bilger W, Björkman O, Fredeen AL, Peñuelas J. Remote-Sensing of the Xanthophyll Cycle and Chlorophyll Fluorescence in Sunflower Leaves and Canopies. Oecologia 1990; 85(1):1-7.

Gamon JA, Huemmrich KF, Peddle DR, Chen J, Fuentes D, Hall FG, Kimball JS, Goetz $\mathrm{S}, \mathrm{Gu}$ J, McDonald KC, Miller JR, Moghaddam M, Rahman AF, Roujean JL, Smith EA, Walthall CL, Zarco-Tejada P, Hu B, Fernandes R, Cihlar J. Remote Sensing in Boreas: Lessons Learned. Remote Sensing of Environment 2004; 89(2):139-162.

Gamon JA, Peñuelas J, Field CB. A Narrow-Waveband Spectral Index That Tracks Diurnal Changes in Photosynthetic Efficiency. Remote Sensing of Environment 1992; 41(1):35-44.

Gamon JA, Rahman AF, Dungan JL, Schildhauer M, Huemmrich KF. Spectral Network (Specnet) - What Is It and Why Do We Need It? Remote Sensing of Environment 2006; 103(3):227-235.

Gamon JA, Surfus JS. Assessing Leaf Pigment Content and Activity With a Reflectometer. New Phytologist 1999; 143(1):105-117.

Gao W. Atmosphere-Biosphere Exchange Flux of Carbon-Dioxide in a Tallgrass Prairie Modeled With Satellite Spectral Data. Journal of Geophysical ResearchAtmospheres 1994; 99(D1):1317-27.

Gautier C, Diak G, Masse S. A Simple Physical Model to Estimate Incident SolarRadiation at the Surface From Goes Satellite Data. Journal of Applied Meteorology 1980; 19(8):1005-12.

Gautier C, Frouin R. Net Surface Solar Irradiance Variability in the Central Equatorial Pacific During 1982-1985. Journal of Climate 1992; 5(1):30-55.

Gitelson AA, Buschmann C, Lichtenthaler HK. The Chlorophyll Fluorescence Ratio F735/F-700 as an Accurate Measure of the Chlorophyll Content in Plants. Remote Sensing of Environment 1999; 69(3):296-302.

Gobron N, Pinty B, Verstraete MM. Theoretical Limits to the Estimation of the Leaf Area Index on the Basis of Visible and Near-Infrared Remote Sensing Data. IEEE Transactions on Geoscience and Remote Sensing 1997; 35(6):1438-1445.

Goel NS, Grier T. Estimation of Canopy Parameters for Inhomogeneous Vegetation Canopies From Reflectance Data .3. Trim - a Model for Radiative-Transfer in Heterogeneous 3-Dimensional Canopies. Remote Sensing of Environment 1988; 25(3):255-293.

Goel NS, Rozehnal I, Thompson RL. A Computer-Graphics Based Model for Scattering From Objects of Arbitrary Shapes in the Optical-Region. Remote Sensing of Environment 1991; 36(2):73-104. 
Goel NS, Strebel DE, Thompson RL. Inversion of Vegetation Canopy Reflectance Models for Estimating Agronomic Variables .2. Use of Angle Transforms and Error Analysis as Illustrated by Suits Model. Remote Sensing of Environment 1984; 14(1-3):77-111.

Goel NS. Models of vegetation canopy reflectance and their use in estimation of biophysical parameters from reflectance data. Remote sensing reviews 1988; 4:1-212.

Goetz SJ, Prince SD, Goward SN, Thawley MM, Small J, Johnston A. Mapping Net Primary Production and Related Biophysical Variables With Remote Sensing: Application to the Boreas Region. Journal of Geophysical ResearchAtmospheres 1999; 104:27719-34.

Goetz SJ, Prince SD. Modelling Terrestrial Carbon Exchange and Storage: Evidence and Implications of Functional Convergence in Light-Use Efficiency. Advances in Ecological Research 1999; 28. 57-92

Goulden ML, Munger JW, Fan SM, Daube BC, Wofsy SC. Exchange of Carbon Dioxide by a Deciduous Forest: Response to Interannual Climate Variability. Science 1996; 271(5255):1576-1578.

Goward S.N., Dye. Evaluating North American net primary productivity with satellite observations. Advances in Space Research 1987; 7:165-174.

Goward SN, Huemmrich KF. Vegetation Canopy PAR Absorptance and the Normalized Difference Vegetation Index - an Assessment Using the Sail Model. Remote Sensing of Environment 1992; 39(2):119-140.

Goward SN, Tucker CJ, Dye DG. North-American Vegetation Patterns Observed With the NOAA-7 Advanced Very High-Resolution Radiometer. Vegetatio 1985; 64(1):3-14.

Guerif M, Duke CL. Adjustment Procedures of a Crop Model to the Site Specific Characteristics of Soil and Crop Using Remote Sensing Data Assimilation. Agriculture Ecosystems \& Environment 2000; 81(1):57-69.

Hall FG, Huemmrich KF, Goetz SJ, Sellers PJ, Nickeson JE. Satellite Remote-Sensing of Surface-Energy Balance - Success, Failures, and Unresolved Issues in Fife. Journal of Geophysical Research-Atmospheres 1992; 97:19061-19089.

Hall FG, Huemmrich KF, Goward SN. Use of Narrow-Band Spectra to Estimate the Fraction of Absorbed Photosynthetically Active Radiation. Remote Sensing of Environment 1990; 32(1):47-54.

Hall FG, Sellers PJ, Strebel DE, Kanemasu ET, Kelly RD, Blad BL, Markham BJ, Wang $J R$, Huemmrich F. Satellite Remote-Sensing of Surface-Energy and Mass 
Balance - Results From Fife. Remote Sensing of Environment 1991; 35(2-3):187199.

Hall FG, Townshend JR, Engman ET. Status of Remote-Sensing Algorithms for Estimation of Land-Surface State Parameters. Remote Sensing of Environment 1995; 51(1):138-156.

Hamilton JG, Delucia EH, George K, Naidu SL, Finzi AC, Schlesinger WH. Forest Carbon Balance Under Elevated Co2. Oecologia 2002; 131(2):250-60.

Heinsch FA, Reeves M, Votava P, Kang S, Milesi C, Zhao M, Glassy J, Jolly WM, Loehman R, Bowker CF, Kimball JS, Nemani RS, Running SW. User's Guide GPP and NPP (MOD17A2/A3) Products NASA MODIS Land Algorithm. Website, accessed April 07 2002. Available at:

http://www.ntsg.umt.edu/modis/MOD17UsersGuide.pdf.

Heinsch FA, Zhao MS, Running SW, Kimball JS, Nemani RR, Davis KJ, Bolstad PV, Cook BD, Desai AR, Ricciuto DM, Law BE, Oechel WC, Kwon H, Luo HY, Wofsy SC, Dunn AL, Munger JW, Baldocchi DD, Xu LK, Hollinger DY, Richardso AD, Stoy PC, Sigueira MBS, Monson RK, Burns SP, Flanagan LB. Evaluation of Remote Sensing Based Terrestrial Productivity From MODIS Using Regional Tower Eddy Flux Network Observations. IEEE Transactions on Geoscience and Remote Sensing 2006; 44(7):1908-25.

Henderson KE, Badhwar GD. An Initial Model for Estimating Soybean Development Stages From Spectral Data. Remote Sensing of Environment 1984; 14(1-3):5563.

Hilker T, Coops NC, Nesic Z, Wulder MA, Black TA. Instrumentation and Approach for Unattended Year Round Tower Based Measurements of Spectral Reflectance. Computers and Electronics in Agriculture 2007; 56(1):72-84.

Huemmrich KF, Goward SN. Vegetation Canopy PAR Absorptance and NDVI: an Assessment for Ten Tree Species With the Sail Model. Remote Sensing of Environment 1997; 61(2):254-69.

Huemmrich KF, Privette JL, Mukelabai M, Myneni RB, Knyazikhin Y. Time-Series Validation of MODIS Land Biophysical Products in a Kalahari Woodland, Africa. International Journal of Remote Sensing 2005; 26(19):4381-98.

Huete A, Didan K, Miura T, Rodriguez EP, Gao X, Ferreira LG. Overview of the Radiometric and Biophysical Performance of the MODIS Vegetation Indices. Remote Sensing of Environment 2002; 83(1-2):195-213.

Huete AR, Didan K, Shimabukuro YE Ratana P, Saleska SR, Hutyra LR, Yang WZ, Nemani RR, Myneni R. Amazon Rainforests Green-up With Sunlight in Dry Season. Geophysical Research Letters 2006; 33(6). 
Humphreys ER, Black TA, Morgenstern K, Cai TB, Drewitt GB, Nesic Z, Trofymow JA. Carbon Dioxide Fluxes in Coastal Douglas-Fir Stands at Different Stages of Development After Clearcut Harvesting. Agricultural and Forest Meteorology 2006; 140(1-4):6-22.

Jacquemoud S, Bacour C, Poilve H, Frangi JP. Comparison of Four Radiative Transfer Models to Simulate Plant Canopies Reflectance: Direct and Inverse Mode. Remote Sensing of Environment 2000; 74(3):471-81.

Jacquemoud S. Inversion of the Prospect + Sail Canopy Reflectance Model From AVIRIS Equivalent Spectra - Theoretical-Study. Remote Sensing of Environment 1993; 44(2-3):281-92.

Janzen HH. Carbon Cycling in Earth Systems - a Soil Science Perspective. Agriculture Ecosystems \& Environment 2004; 104(3):399-417.

Kergoat L, Lafont S, Douville H, Berthelot B, Dedieu G, Planton S, Royer JF. Impact of Doubled $\mathrm{CO}_{2}$ on Global-Scale Leaf Area Index and Evapotranspiration:

Conflicting Stomatal Conductance and LAI Responses. Journal of Geophysical Research-Atmospheres 2002; 107(D24).

Kharouk VI, Middleton EM, Spencer SL, Rock BN, Williams DL. Aspen Bark Photosynthesis and Its Significance to Remote-Sensing and Carbon Budget Estimates in the Boreal Ecosystem. Water Air Soil Pollut 1995; 82(1-2):483-97.

Khurshid KS, Staenz K, Sun LX Neville R, White, HP, Bannari A, Champagne CM, Hitchcock R. Preprocessing of EO-1 Hyperion Data. Canadian Journal of Remote Sensing 2006; 32(2):84-97.

Kljun N, Calanca P, Rotachhi MW, Schmid HP. A Simple Parameterisation for Flux Footprint Predictions. Boundary-Layer Meteorology 2004; 112(3):503-523.

Knyazikhin Y, Martonchik JV, Myneni RB, Diner DJ, Running SW. Synergistic Algorithm for Estimating Vegetation Canopy Leaf Area Index and Fraction of Absorbed Photosynthetically Active Radiation From MODIS and MISR Data. Journal of Geophysical Research-Atmospheres 1998; 103(D24):32257-32275.

Knyazikhin Y, Yang W, Dong H, Bin T, Shabanov N, Myneni R. MODIS LAI and fPAR Product on Global, Regional and Local Scales Fall Meeting 2003 of the American Geophysical Union. 2003.

Knyazikhin Y., J. Glassy, J. L. Privette, Running SW, Nemani R, Zhang, Y, Tian, Y, Wang, Y, Morissette JT, Glassy J, Votava P, Lotsch A. MODIS Leaf Area Index (LAl) and Fraction of Photosynthetically Active Radiation Absorbed by Vegetation (f $\left.f_{\text {PAR }}\right)$ Product (MOD15) Algorithm Theoretical Basis Document, 1999. Website accessed 04/2007. Available at http://www.ntsg.umt.edu/modis/ATBD/ATBD_MOD15_v21.pdf 
Kolber Z, Klimov D, Ananyev G, Rascher U, Berry J, Osmond B. Measuring Photosynthetic Parameters at a Distance: Laser Induced Fluorescence Transient (Lift) Method for Remote Measurements of Photosynthesis in Terrestrial Vegetation. Photosynthesis Research 2005; 84(1-3):121-9.

Landsberg JJ, Prince SD, Jarvis PG, McMutrie RE, Luxmore R. Energy conversion and use in forests: The analysis of forest production in terms of utilization efficiency. 1997. (H.L. Gholz, K. Nakane and H. Shimoda, eds.) Kluwer Acad. Publ., Dordrecht, The Netherlands. pp. 273-298.

Leroy M, Deuze JL, Breon FM, Hautecoeur O, Herman M, Buriez JC, Tanre D, Bouffies $\mathrm{S}$, Chazette P, Roujean JL. Retrieval of Atmospheric Properties and Surface Bidirectional Reflectances Over Land From POLDER/ADEOS. Journal of Geophysical Research-Atmospheres 1997; 102(D14):17023-17037.

Leuning R, Hughes D, Daniel P, Coops NC, Newnham G. A Multi-Angle Spectrometer for Automatic Measurement of Plant Canopy Reflectance Spectra. Remote Sensing of Environment 2006; 103(3):236-245.

Li XW, Strahler AH, Woodcock CE. A Hybrid Geometric Optical-Radiative Transfer Approach for Modeling Albedo and Directional Reflectance of Discontinuous Canopies. IEEE Transactions on Geoscience and Remote Sensing 1995; 33(2):466-80.

Li XW, Strahler AH. Geometric-Optical Modeling of a Conifer Forest Canopy. IEEE Transactions on Geoscience and Remote Sensing 1985; 23(5):705-21.

Liang SL, Zheng T, Liu RG, Fang HL, Tsay SC, Running S. Estimation of Incident Photosynthetically Active Radiation From Moderate Resolution Imaging Spectrometer Data. Journal of Geophysical Research-Atmospheres 2006; 111(D15).

Liu WT, Kogan FN. Monitoring Regional Drought Using the Vegetation Condition Index. International Journal of Remote Sensing 1996; 17(14):2761-2782.

Liu X, Smith WL, Zhou DK, Larar A. Principal Component-Based Radiative Transfer Model for Hyperspectral Sensors: Theoretical Concept. Applied Optics 2006; 45(1):201-209.

Lopez S, Gonzalez F, Llop R, Cuevas JM. An Evaluation of the Utility of NOAA AVHRR Images for Monitoring Forest-Fire Risk in Spain. International Journal of Remote Sensing 1991; 12(9):1841-1851.

Los SO, Justice CO, Tucker CJ. A Global 1-Degrees-by-1-Degrees NDVI Data Set for Climate Studies Derived From the Gimms Continental NDVI Data. International Journal of Remote Sensing 1994; 15(17):3493-518. 
Los SO, North PRJ, Grey WMF, Barnsley MJ. A Method to Convert AVHRR Normalized Difference Vegetation Index Time Series to a Standard Viewing and Illumination Geometry. Remote Sensing of Environment 2005; 99(4):400-11.

Luo YQ, Reynolds JF. Validity of Extrapolating Field Co2 Experiments to Predict Carbon Sequestration in Natural Ecosystems. Ecology 1999; 80(5):1568-1583.

Lyapustin A, Wang Y, Kahn R, Xiong J, Ignatov A, Wolfe R, Wu A. Holben B, Bruegge C. Analysis of MODIS-MISR Calibration Differences Using Surface Albedo Around Aeronet Sites and Cloud Reflectance. Remote Sensing of Environment 2007; 107(1-2):12-21.

Mariscal MJ, Martens SN, Ustin SL, Chen JQ, Weiss SB, Roberts DA. LightTransmission Profiles in an Old-Growth Forest Canopy: Simulations of Photosynthetically Active Radiation by Using Spatially Explicit Radiative Transfer Models. Ecosystems 2004; 7(5):454-467.

Martin ME, Aber JD. High Spectral Resolution Remote Sensing of Forest Canopy Lignin, Nitrogen, and Ecosystem Processes. Ecological Applications 1997; 7(2):431-443.

Meroni M, Colombo R, Panigada C. Inversion of a Radiative Transfer Model With Hyperspectral Observations for Lai Mapping in Poplar Plantations. Remote Sensing of Environment 2004; 92(2):195-206.

Meroni M, Colombo R. Leaf Level Detection of Solar Induced Chlorophyll Fluorescence by Means of a Subnanometer Resolution Spectroradiometer. Remote Sensing of Environment 2006; 103(4):438-448.

Monteith JL. Climate and Efficiency of Crop Production in Britain. Philosophical Transactions of the Royal Society of London Series B- Biological Sciences 1977; 281(980):277-294.

Monteith JL. Solar-Radiation and Productivity in Tropical Ecosystems. Journal of Applied Ecology 1972; 9(3):747-766.

Morgenstern K, Black TA, Humphreys ER, Griffis TJ, Drewitt GB, Cai TB, Nesic Z, Spittlehouse DL, Livingstone NJ. Sensitivity and Uncertainty of the Carbon Balance of a Pacific Northwest Douglas-Fir Forest During an El Nino La Nina Cycle. Agricultural and Forest Meteorology 2004; 123(3-4):201-219.

Moya I, Camenen L, Evain S, Goulas Y, Cerovic ZG, Latouche G, Flexas J, Ounis A. A New Instrument for Passive Remote Sensing 1. Measurements of SunlightInduced Chlorophyll Fluorescence. Remote Sensing of Environment 2004; 91(2):186-197. 
Myneni RB, Asrar G, Hall FG. A 3-Dimensional Radiative-Transfer Method for Optical Remote-Sensing of Vegetated Land Surfaces. Remote Sensing of Environment 1992; 41(2-3):105-121.

Myneni RB, Hoffman S, Knyazikhin Y, Privette JL, Glassy J, Tian Y, Wang Y, Song X, Zhang Y, Smith GR, Lotsch A, Friedl M, Morisette JT, Votava P, Nemani RR, Running SW. Global Products of Vegetation Leaf Area and Fraction Absorbed Par From Year One of Modis Data. Remote Sensing of Environment 2002; 83(12):214-231.

Myneni RB, Nemani RR, Running SW. Estimation of Global Leaf Area Index and Absorbed Par Using Radiative Transfer Models. IEEE Transactions on Geoscience and Remote Sensing 1997; 35(6):1380-1393.

Myneni RB, Ross J, Asrar G. A Review on the Theory of Photon Transport in Leaf Canopies. Agricultural and Forest Meteorology 1989; 45(1-2):1-153.

Myneni RB, Williams DL. On the Relationship Between $\mathrm{F}_{\text {APAR }}$ and NDVI. Remote Sensing of Environment 1994; 49(3):200-211.

Nemani RR, Running SW. Estimation of Regional Surface-Resistance to Evapotranspiration From NDVI and Thermal-IR AVHRR Data. Journal of Applied Meteorology 1989; 28(4):276-284.

Nichol CJ, Huemmrich KF, Black TA, Jarvis PG, Walthall CL, Grace J, Hall FG. Remote Sensing of Photosynthetic-Light-Use Efficiency of Boreal Forest. Agricultural and Forest Meteorology 2000; 101(2-3):131-142.

Nichol CJ, Lloyd J, Shibistova O, Arneth A, Roser C, Knohl A, Matsubara S, Grace J. Remote Sensing of Photosynthetic-Light-Use Efficiency of a Siberian Boreal Forest. Tellus Series B-Chemical and Physical Meteorology 2002; 54(5):677-687.

Ollinger SV, Smith ML, Martin ME, Hallett RA, Goodale CL, Aber JD. Regional Variation in Foliar Chemistry and N Cycling Among Forests of Diverse History and Composition. Ecology 2002; 83(2):339-55.

Peñuelas J, Filella I, Gamon JA. Assessment of Photosynthetic Radiation-Use Efficiency With Spectral Reflectance. New Phytologist 1995; 131(3):291-6.

Peñuelas J, Gamon JA, Fredeen AL, Merino J, Field CB. Reflectance Indexes Associated With Physiological-Changes in Nitrogen-Limited and Water-Limited Sunflower Leaves. Remote Sensing of Environment 1994; 48(2):135-46.

Pinker RT, Ewing JA. Modeling Surface Solar-Radiation - Model Formulation and Validation. Journal of Climate and Applied Meteorology 1985; 24(5):389-401.

Pinker RT, Laszlo I. Modeling Surface Solar Irradiance for Satellite Applications on a Global Scale. Journal of Applied Meteorology 1992; 31(2):194-211. 
Prihodko L, Goward SN. Estimation of air temperature from remotely sensed surface observations. Remote Sensing of Environment 1997; 60 (3): 335-346.

Potter CS, Coughlan JC, Brooks V. Investigations of Boreas Spatial Data in Support of Regional Ecosystem Modeling. Journal of Geophysical Research-Atmospheres 1999; 104(D22):27771-27788.

Potter CS, Randerson JT, Field CB, Matson PA, Vitousek PM, Mooney HA, Klooster SA.Terrestrial Ecosystem Production - a Process Model-Based on Global Satellite and Surface Data. Global Biogeochemical Cycles 1993; 7(4):811-841.

Prevot L, Chauki H, Troufleau D, Weiss M, Baret F, Brisson N. Assimilating Optical and Radar Data Into the Stics Crop Model for Wheat. Agronomie 2003; 23(4):297303.

Price JC. Estimating Leaf-Area Index From Satellite Data. IEEE Transactions on Geoscience and Remote Sensing 1993; 31(3):727-34.

Prince SD, Goward SN. Evaluation of the NOAA/NASA Pathfinder AVHRR Land Data Set for Global Primary Production Modelling. International Journal of Remote Sensing 1996; 17(1):217-21.

Prince SD, Goward SN. Global Primary Production: a Remote Sensing Approach. Journal of Biogeography 1995; 22(4-5):815-35.

Prince SD. Satellite Remote-Sensing of Primary Production - Comparison of Results for Sahelian Grasslands 1981-1988. International Journal of Remote Sensing 1991; 12(6):1301-11.

Privette JL, Emery WJ, Schimel DS. Inversion of a Vegetation Reflectance Model With NOAA AVHRR Data. Remote Sensing of Environment 1996; 58(2):187-200.

Rahman AF, Gamon JA, Fuentes DA, Roberts DA, Prentiss D. Modeling Spatially Distributed Ecosystem Flux of Boreal Forest Using Hyperspectral Indices From AVIRIS Imagery. Journal of Geophysical Research-Atmospheres 2001; 106(D24):33579-33591.

Rahman AF, Sims DA, Cordova VD, El-Masri BZ. Potential of MODIS Evi and Surface Temperature for Directly Estimating Per-Pixel Ecosystem C Fluxes. Geophysical Research Letters 2005; 32(19).

Rao CRN. Photosynthetically Active Components of Global Solar-Radiation Measurements and Model Computations. Archives for Meteorology Geophysics and Bioclimatology Series B-Theoretical and Applied Climatology 1984; 34(4):353-364.

Rascher U, Liebig M, Luttge U. Evaluation of Instant Light-Response Curves of Chlorophyll Fluorescence Parameters Obtained With a Portable Chlorophyll 
Fluorometer on Site in the Field. Plant Cell and Environment 2000; 23(12):1397405.

Reich PB, Walters MB, Ellsworth DS. From Tropics to Tundra: Global Convergence in Plant Functioning. Proceedings of the National Academie of Science USA 1997; 94(25):13730-4.

Rosema A, Snel JFH, Zahn H, Buurmeijer WF, Van Hove LWA. The Relation Between Laser-Induced Chlorophyll Fluorescence and Photosynthesis. Remote Sensing of Environment 1998; 65(2):143-54.

Running SW, Baldocchi DD, Turner DP, Gower ST, Bakwin PS, Hibbard KA. A Global Terrestrial Monitoring Network Integrating Tower Fluxes, Flask Sampling, Ecosystem Modeling and Eos Satellite Data. Remote Sensing of Environment 1999; 70(1):108-27.

Running SW, Nemani RR, Heinsch FA, Zhao MS, Reeves M, Hashimoto H. A Continuous Satellite-Derived Measure of Global Terrestrial Primary Production. Bioscience 2004; 54(6):547-60.

Running SW, Nemani RR. Relating Seasonal Patterns of the AVHRR Vegetation Index to Simulated Photosynthesis and Transpiration of Forests in Different Climates. Remote Sensing of Environment 1988; 24(2):347-67.

Running SW, Queen L, Thornton M. The Earth Observing System and Forest Management. Journal of Forestry 2000; 98(6):29-31.

Sellers PJ, Hall FG, Kelly RD, Black A, Baldocchi D, Berry J, Ryan M, Ranson KJ, Crill PM, Lettenmaier DP, Margolis H, Cihlar J, Newcomer J, Fitzjarrald D, Jarvis PG, Gower ST, Halliwell D, Williams D, Goodison B, Wickland DE, Guertin FE.

Boreas in 1997: Experiment Overview, Scientific Results, and Future Directions. Journal of Geophysical Research-Atmospheres 1997; 102(D24):28731-28769.

Sellers PJ, Hall FG. Fife in 1992 - Results, Scientific Gains, and Future-Research Directions. Journal of Geophysical Research-Atmospheres 1992; 97(D17):19091-19109.

Sellers PJ, Heiser MD, Hall FG. Relations Between Surface Conductance and Spectral Vegetation Indexes at Intermediate $\left(100 \mathrm{~m}^{2}\right.$ to $\left.15 \mathrm{~km}^{2}\right)$ Length Scales. Journal of Geophysical Research-Atmospheres 1992; 97(D17):19033-19059.

Sellers PJ, Los SO, Tucker CJ, Justice CO, Dazlich DA, Collatz GJ, Randall DA. A Revised Land Surface Parameterization (SiB2) for Atmospheric GCMs .2. The Generation of Global Fields of Terrestrial Biophysical Parameters From Satellite Data. Journal of Climate 1996; 9(4):706-737.

Sellers PJ, Meeson BW, Hall FG, Asrar, G, Murphy RE, Schiffer RA, Bretherton FP, Dickinson RE, Ellingson RG, Field CB, Huemmrich KF, Justice CO, Melack JM, 
Roulet NT, Schimel DS, Try PD. Remote-Sensing of the Land-Surface for Studies of Global Change - Models, Algorithms, Experiments. Remote Sensing of Environment 1995; 51(1):3-26.

Sellers PJ, Randall DA, Collatz GJ, Berry JA, Field CB, Dazlich DA, Zhang C, Collelo GD, Bounoua L. A Revised Land Surface Parameterization (Sib2) for Atmospheric GCMs .1. Model Formulation. Journal of Climate 1996; 9(4):676705.

Sellers PJ, Tucker CJ, Collatz GJ, Los SO, Justice CO, Dazlich DA, Randall DA. A Global 1-Degrees-by-1-Degrees NDVI Data Set for Climate Studies .2. The Generation of Global Fields of Terrestrial Biophysical Parameters From the NDVI. International Journal of Remote Sensing 1994; 15(17):3519-45.

Sellers PJ. Canopy Reflectance, Photosynthesis and Transpiration. International Journal of Remote Sensing 1985; 6(8):1335-72.

Sellers PJ. Canopy Reflectance, Photosynthesis, and Transpiration 2. The Role of Biophysics in the Linearity of Their Interdependence. Remote Sensing of Environment 1987; 21(2):143-183.

Sims DA, Luo HY, Hastings S, Oechel WC, Rahman AF, Gamon JA. Parallel Adjustments in Vegetation Greenness and Ecosystem Co2 Exchange in Response to Drought in a Southern California Chaparral Ecosystem. Remote Sensing of Environment 2006; 103(3):289-303.

Sims DA, Rahman AF, Cordova VD, Baldocchi DD, Flanagan LB, Goldstein AH, Hollinger DY, Misson L, Monson RK, Schmid HP, Wofsy SC, Xu LK. Midday Values of Gross Co2 Flux and Light Use Efficiency During Satellite Overpasses Can Be Used to Directly Estimate Eight-Day Mean Flux. Agricultural and Forest Meteorology 2005; 131(1-2):1-12.

Smith ML, Martin ME, Plourde L, Ollinger SV. Analysis of Hyperspectral Data for Estimation of Temperate Forest Canopy Nitrogen Concentration: Comparison Between an Airborne (AVIRIS) and a Spaceborne (Hyperion) Sensor. IEEE Transactions on Geoscience and Remote Sensing 2003; 41(6):1332-7.

Stylinski CD, Gamon JA, Oechel WC. Seasonal Patterns of Reflectance Indices, Carotenoid Pigments and Photosynthesis of Evergreen Chaparral Species. Oecologia 2002; 131(3):366-374.

Szeicz G. Solar-Radiation for Plant-Growth. Journal of Applied Ecology 1974; 11(2):617-636.

Tarpley JD. Estimating Incident Solar-Radiation at the Surface From Geostationary Satellite Data. Journal of Applied Meteorology 1979; 18(9):1172-1181. 
Tucker CJ, Fung IY, Keeling CD, Gammon RH. Relationship Between Atmospheric Co2 Variations and a Satellite-Derived Vegetation Index. Nature 1986; 319(6050):195-199.

Tucker CJ, Jones WH, Kley WA, Sundstrom GJ. A 3-Band Hand-Held Radiometer for Field Use. Science 1981; 211(4479):281-283.

Tucker CJ, Justice CO, Prince SD. Monitoring the Grasslands of the Sahel 1984-1985. International Journal of Remote Sensing 1986; 7(11):1571-1581.

Tucker CJ, Sellers PJ. Satellite Remote-Sensing of Primary Production. International Journal of Remote Sensing 1986; 7(11):1395-416.

Tucker CJ. Red and Photographic Infrared Linear Combinations for Monitoring Vegetation. Remote Sensing of Environment 1979; 8(2):127-150.

Turner DP, Ritts WD, Cohen WB, Gower ST, Zhao MS, Running SW, Wofsy SC, Urbanski S, Dunn AL, Munger JW. Scaling Gross Primary Production (GPP) Over Boreal and Deciduous Forest Landscapes in Support of MODIS GPP Product Validation. Remote Sensing of Environment 2003a; 88(3):256-270.

Turner DP, Urbanski S, Bremer D, Wofsy SC, Meyers T, Gower ST, Gregory M. A Cross-Biome Comparison of Daily Light Use Efficiency for Gross Primary Production. Global Change Biology 2003b; 9(3):383-395.

Van Laake PE, Sanchez-Azofeifa GA. Mapping Par Using MODIS Atmosphere Products. Remote Sensing of Environment 2005; 94(4):554-563.

Van Laake PE, Sanchez-Azofeifa GA. Simplified Atmospheric Radiative Transfer Modelling for Estimating Incident Par Using MODIS Atmosphere Products. Remote Sensing of Environment 2004; 91(1):98-113.

Vidal A, Pinglo F, Durand H, Devauxros C, Maillet A. Evaluation of a Temporal Fire Risk Index in Mediterranean Forests From NOAA Thermal Ir. Remote Sensing of Environment 1994; 49(3):296-303.

Walthall CL, Kim M, Williams DL, Meeson, BC, Agbu PA, Newcomer JA, Levine ER.Data Sets for Modeling - a Retrospective Collection of Bidirectional Reflectance and Forest Ecosystems Dynamics Multisensor Aircraft Campaign Data Sets. Remote Sensing of Environment 1993; 46(3):340-346.

Wanner W, Li X, Strahler AH. On the Derivation of Kernels for Kernel-Driven Models of Bidirectional Reflectance. Journal of Geophysical Research-Atmospheres 1995; 100(D10):21077-89.

Waring RH, Coops NC, Fan W, Nightingale JM. MODIS Enhanced Vegetation Index Predicts Tree Species Richness Across Forested Ecoregions in the Contiguous Usa. Remote Sensing of Environment 2006; 103(2):218-26. 
Weiss A, Norman JM. Partitioning Solar-Radiation Into Direct and Diffuse, Visible and Near-Infrared Components. Agricultural and Forest Meteorology 1985; 34(23):205-13.

Wessman CA, Aber JD, Peterson DL, Melillo JM. Remote-Sensing of Canopy Chemistry and Nitrogen Cycling in Temperate Forest Ecosystems. Nature 1988; 335(6186):154-6.

Wigneron JP, Calvet JC, Pellarin T, Van De Griend AA, Berger M, Ferrazzoli P. Retrieving Near-Surface Soil Moisture From Microwave Radiometric Observations: Current Status and Future Plans. Remote Sensing of Environment 2003; 85(4):489-506.

Xiao XM, Zhang QY, Braswell B, Urbanski S, Boles S, Wofsy S, Berrien M, Ojima D. Modeling Gross Primary Production of Temperate Deciduous Broadleaf Forest Using Satellite Images and Climate Data. Remote Sensing of Environment 2004; 91(2):256-270.

Zarco-Tejada PJ, Miller JR, Mohammed GH, Noland TL. Chlorophyll Fluorescence Effects on Vegetation Apparent Reflectance: I. Leaf-Level Measurements and Model Simulation. Remote Sensing of Environment 2000; 74(3):582-95. 